\title{
Nonindigenous Ascidians in Tropical Waters ${ }^{1}$
}

\author{
Gretchen Lambert ${ }^{2}$
}

\begin{abstract}
Ascidians (invertebrate chordates) are abundant in many ports around the world. Most of them are nonindigenous species that tolerate wide fluctuations in temperature, salinity, and even pollution. These sessile suspension feeders have a rapid growth rate, usually a short life span of a few months, reach sexual maturity when only a few weeks old, and produce large numbers of shortlived nonfeeding planktonic larvae. They thrive on marina floats, pilings, buoys, and boat bottoms in protected harbors where there is reduced wave action and enhanced nutrients from anthropogenic activities. Nonindigenous ascidians frequently overgrow oysters and mussels, which are often cultivated in or near busy harbors. Adult ascidians on ship or barge hulls may survive transport over thousands of kilometers to harbors with conditions similar to those they left; occasionally live larvae have also been recovered from ships' ballast water. U.S. Navy dry dock movements between major Pacific ports have transported large masses of fouling nonindigenous taxa, including ascidians. Transfer between culture sites of oysters, mussels, and associated lines and nets may provide an additional mode of transport. Once nonindigenous ascidians become established, they provide large local sources of larvae for further possible invasions into additional harbors and nearby natural marine communities. Invasive species include both solitary and colonial forms, with a preponderance of large solitary species that thrive in highly disturbed habitats. In Guam, for example, most nonindigenous ascidians are confined to harbor structures and have not as yet significantly colonized natural reefs. In contrast, healthy natural benthic regions both inside and outside the harbors of Guam are usually stable coral reef communities containing a high diversity, but very low biomass, of native colonial ascidian species. However, in several areas of the Caribbean a native colonial didemnid has recently begun overgrowing coral reefs. In the Gulf of Mexico a nonindigenous didemnid now covers many offshore oil rigs and may become a threat to neighboring natural reefs. Additional data on nonindigenous ascidians in Australia, Palau, Hawaici, and the Mediterranean are included. Although serious invasion of coral reefs has not yet been reported, more studies and regular monitoring are needed.
\end{abstract}

INTRODUCTrons of nonindigenous ascidians into harbors in both tropical and temperate waters are now commonplace, with the tempo

${ }^{1}$ Paper presented at the Ninth International Coral Reef Symposium, Bali, Indonesia, 27 October 2000. Manuscript accepted 2 January 2002.

${ }^{2}$ University of Washington Friday Harbor Laboratories, Friday Harbor, Washington 98250. Mailing address: 12001 11th Avenue NW, Seattle, Washington 98177 (phone: 206-365-3734; E-mail: glambert@ fullerton.edu).

Pacific Science (2002), vol. 56, no. 3:291-298

(C) 2002 by University of Hawai'i Press

All rights reserved of introductions increasing (for reviews see Monniot et al. 1991, Lambert and Lambert 1998, Coles et al. 1999). Ascidians are invertebrate members of the phylum Chordata, with a sessile suspension-feeding adult and a short-lived nonfeeding motile larva. Colonial species brood their young and release mature larvae into the water, but most others spawn eggs and sperm that develop in about $24 \mathrm{hr}$ into swimming larvae with an average larval duration of 12-24 hr. Because the larval stage is so short (perhaps only a few minutes between release and settlement in colonial forms), their primary mode of anthropogenic transport is probably boat hulls or other 
fouled surfaces. Movement between culture sites of fouled nets and shells used in mariculture, for example, may inadvertently transport nonindigenous ascidians (unpubl. data), as were burrowing polychaetes on oysters imported from Maine into Hawai'i in 1990 (Bailey-Brock 2000). Although ascidian larvae are known to survive transport in ballast water (Carlton and Geller 1993), this may not be their major mode of human-influenced transport. Sampling of U.S. Navy dry dock hulls both before and after their movement across thousands of kilometers in the Pacific (including Honolulu to Guam in July 1999 and San Diego to Honolulu in December 1999) has shown that many adult ascidians arrive alive (G. Paulay and S. Godwin, pers. comm.). When a bridge collapsed in Palau in 1996, a floating pontoon bridge was towed there from China the following year; it arrived carrying many live fouling organisms including ascidians ( $\mathrm{P}$. Colin, pers. comm.). By whatever means they achieve transport, the same nonindigenous ascidians are often recorded from widely separated localities (Boyd et al. 1990, Monniot et al. 1991, Monniot and Monniot 1994, 1996, 2001, Lambert and Lambert 1998).

Many nonindigenous ascidians reach sexual maturity in just a few weeks and have long breeding seasons (Lambert and Lambert 1998). They tolerate wide fluctuations in temperature and salinity and acclimate rapidly to these changes (Sims 1984, Nomaguchi et al. 1997). Nonindigenous ascidians also tolerate various types of pollution and are known to sequester or use metal ions (Monniot et al. 1993, 1994, Naranjo et al. 1996, Sings et al. 1996). Diplosoma listerianum provides an excellent example of a potential nonindigenous ascidian; it now has a global distribution. In addition to having many of the traits listed above, genetically different colonies of $D$. listerianum frequently fuse and the resulting chimeras have been shown to have enhanced adaptability (Sommerfeldt and Bishop 1999). The zooids can store exogenous sperm for several weeks (Bishop and Sommerfeldt 1996), and like other colonial ascidians the larvae are brooded and released only when competent to settle. Although having the ability to attach tenaciously to substrates, the tunic is flaccid and tears easily. If even a small bit adheres to any organisms that are transported, it can rapidly colonize a new substrate and may already be in reproductive mode. Because many colonies are actually chimeras, the gametes of zooids within a single colony can cross-fertilize.

Nonindigenous ascidians rapidly colonize artificial substrates in harbors, such as pilings, floating marina docks, boat hulls, and buoys. The epifauna on these structures is often nearly completely composed of nonindigenous species of various taxa, frequently dominated by huge numbers and biomass of nonindigenous ascidians (Lambert and Lambert 1998). The important question is, do these invaders also colonize neighboring natural reef areas, outcompeting and replacing native species, or do they remain confined to artificial surfaces within harbors? This question is highly relevant not only because of the increasingly large number of artificial surfaces associated with ever-expanding marinas to service the rapidly growing pleasure boat industry, but also because more and more fish and wildlife and parks departments are establishing artificial reefs to attract fish for sports fishermen and snorkeling and scuba diving hobbyists.

Only a few comparative studies, especially long-term, of neighboring natural versus artificial habitats have been done. Glasby and Connell (Connell and Glasby 1999, Connell 2000, Glasby 2000) concluded after many years of study of Sydney Harbour in Australia that pilings and floating pontoons provide a unique set of habitats that cannot be considered equivalent to adjacent natural benthic substrates. The environmental conditions they are subject to, the particular surfaces exposed, and many other variables result in an epibiota quite different from that of adjacent benthic areas, and there is very little overlap in species composition even after several years. Connell (2000) showed that it is not the nature of the surface itself but its location that is most important in determining which species will colonize it. Surfaces composed of either artificial or natural materials attached to or suspended from floating pontoons will be 
colonized by the same species as inhabit the pontoons; similarly, both artificial and natural surfaces placed in a benthic ecosystem will be colonized by the same types of organisms as occur in that ecosystem. In Sydney Harbour, pilings and pontoons have increased the overall biodiversity and biomass without any apparent changes in the benthic ecosystems (Connell and Glasby 1999).

Paulay et al. (2001 and unpubl. data) reported similar results in a large-scale comparison of the epibiota of artificial structures in and around Apra Harbor, Guam, with natural reef areas. Although there is some overlap of species, for the most part the biota of these adjoining habitats are very different; based on the work of Glasby and Connell (as mentioned earlier), we can assume that these artificial and natural habitats are subjected to very different environment conditions. Floating docks, buoys, and pilings are primarily colonized by nonindigenous ascidians, whereas native species dominate the natural reefs. Twenty-one species (18\%) are found on artificial surfaces only, 78 species $(67 \%)$ are found on natural substrates only, and 18 species $(15 \%)$ are found on both artificial and natural substrates, a total of 117 species. Of the 15 known invasive ascidian species in Guam that are also reported as nonindigenous in many other areas (Monniot et al. 1991, Monniot and Monniot 1994, 1996, Coles et al. 1999), all were found on artificial surfaces; three of these also occurred on nearby reefs: Botryllus niger, Cnemidocarpa irene, and Herdmania pallida. On natural reefs these three species were small, sparse, and formed only a negligible part of the reef fauna, in striking contrast to their larger size and numbers on artificial substrates. (One immature Microcosmus sp., possibly $M$. exasperatus but too small to identify, was also found on a reef but not included in Table 1.) Five of the remaining 9 of the 21 species recorded only from artificial surfaces are as yet identified only to genus; the other four are considered cryptogenic.

In Table 1 the criteria for a designation of introduced are that the species (1) be restricted to artificial surfaces and (2) have an extra-Indo-West-Pacific distribution; if only one of these criteria apply, the species is considered cryptogenic. Based on these criteria, nine are listed as introduced and 18 as cryptogenic. An additional four included as cryptogenic were found predominantly on artificial substrates with only a few very small specimens collected from natural areas (Peropbora sagamiensis, Pyura curvigona, P. bonu, and $P$. cf. robusta), though their distribution is not extra-Indo-West-Pacific.

Of the 31 species considered introduced or cryptogenic in Guam (Table 1), 16 are colonial and 15 are solitary. Half of the colonial forms belong to the order Aplousobranchia. The Phlebobranchia are also well represented with five species, two of which are colonial and three are solitary. The largest group is the Stolidobranchia, with seven colonial and 12 solitary species. All of the 78 species occurring only on natural substrates are considered native/indigenous. Of these 78, 69 $(88 \%)$ are colonial. Thus $48 \%$ of introduced/ cryptogenic species are solitary, but most of the native/indigenous species are colonial.

Fay and Vallee (1979) reported 39 species of ascidians from the Channel Islands off the southern California mainland. Fourteen (36\%) were solitary; 25 (64\%) were colonial. In comparing the ascidian distribution between mainland and islands, they found a preponderance of viviparity in the island species and concluded that this was a strategy to reduce gamete loss. However, nearly all the viviparous species were colonial. Thus another ecological factor that must be considered is growth form: colonial species are low encrusting mats; solitary species project into the water column. The high-energy surf zone environment present around the Channel Islands as well as on the reef edges around Guam favors ascidians with both a low encrusting form and viviparous mode of reproduction. All 69 colonial native/indigenous species of Guam ascidians occurring only on natural substrates are viviparous. In constrast, artificial structures such as buoys, wharf pilings, and floating docks are located in harbors where there is much less wave action. The epibionts that colonize these structures, and indeed the large-scale fouling communities that form, can do so only because of the protected environment. As Berrill (1955) pointed 
TABLE 1

Guam Ascidians Considered Introduced or Cryptogenic

\begin{tabular}{|c|c|c|c|c|c|}
\hline Species & Status & Apra Harbor & $\begin{array}{l}\text { Extra-Indo- } \\
\text { West-Pacific } \\
\text { Distribution }\end{array}$ & $\begin{array}{l}\text { Restriction } \\
\text { to Artificial } \\
\text { Substrates }\end{array}$ & Solitary/Colonial \\
\hline \multicolumn{6}{|l|}{ Aplousobranchia } \\
\hline Gold-green compound & Cryptogenic & 1 & $?$ & 1 & C \\
\hline Didemnum perlucidum & Introduced & 1 & 1 & 1 & C \\
\hline Didemnum psammatbodes & Cryptogenic & 0 & 1 & 0 & $\mathrm{C}$ \\
\hline Diplosoma listerianum & Introduced & 1 & 1 & 1 & $\mathrm{C}$ \\
\hline Diplosoma "fluffy" & Cryptogenic & 1 & $?$ & 1 & $\mathrm{C}$ \\
\hline Lissoclinum fragile & Introduced & 1 & 1 & 1 & C \\
\hline Polyclinum constellatum & Introduced & 1 & 1 & 1 & C \\
\hline \multicolumn{6}{|l|}{ Phlebobranchia } \\
\hline Perophora multiclatbrata & Cryptogenic & 1 & 1 & 0 & $\mathrm{C}$ \\
\hline Perophora sagamiensis & Cryptogenic & 1 & 0 & 0 & C \\
\hline Ascidia sydneiensis & Introduced & 1 & 1 & 1 & $\mathrm{~s}$ \\
\hline Ascidia sp. B & Cryptogenic & 1 & $?$ & 1 & $\mathrm{~S}$ \\
\hline Phallusia nigra & Introduced & $i$ & 1 & 1 & $S$ \\
\hline \multicolumn{6}{|l|}{ Stolidobranchia } \\
\hline Botryllus cf. simodensis & Cryptogenic & 1 & 0 & 1 & $\mathrm{C}$ \\
\hline Botryllus niger & Cryptogenic & 1 & 1 & 0 & $\mathrm{C}$ \\
\hline Botryllus sp. A & Cryptogenic & 1 & $?$ & 1 & C \\
\hline Botryllus sp. B & Cryptogenic & 1 & ? & 1 & C \\
\hline Cnemnidocarpa irene & Cryptogenic & 1 & 1 & 0 & $\mathrm{~s}$ \\
\hline Polyandrocarpa sagamiensis & Cryptogenic & 1 & 0 & 1 & $\mathrm{C}$ \\
\hline Polycarpa aurita & Cryptogenic & 1 & 0 & 1 & $\mathrm{~S}$ \\
\hline Styela canopus & Introduced & 1 & 1 & 1 & $\mathrm{~S}$ \\
\hline Symplegma brakenbielmi & Introduced & 1 & 1 & 1 & C \\
\hline Symplegrma sp. A & Cryptogenic & 1 & ? & 1 & C \\
\hline Herdmania insolita & Cryptogenic & 1 & $?$ & 1 & $\mathrm{~S}$ \\
\hline Herdmania pallida & Cryptogenic & 1 & 1 & 0 & $\mathrm{~S}$ \\
\hline Microcosmus exasperatus & Introduced & 1 & 1 & 1 & $\mathrm{~S}$ \\
\hline Microcosmus belleri & Cryptogenic & 1 & 1 & 0 & $\mathrm{~S}$ \\
\hline Microcosmus pupa & Cryptogenic & 1 & 0 & 1 & $\mathrm{~S}$ \\
\hline Pyura confragosa & Cryptogenic & 1 & 0 & 1 & $\mathrm{~S}$ \\
\hline Pyura curvigona & Cryptogenic & 1 & 0 & 0 & S \\
\hline Pyura bonu & Cryptogenic & 1 & 0 & 0 & $\mathrm{~S}$ \\
\hline Pyura cf. robusta & Cryptogenic & 1 & 0 & 0 & $\mathrm{~S}$ \\
\hline
\end{tabular}

out, budding in colonial ascidians is "primarily a means of extending the living, reproducing ascidian entity in two rather than three dimensions, in relation to the exploitation of flat surfaces on which uniform threedimensional growth leads to increasing insecurity of foothold."

In Palau, preliminary data indicate that, as in Guam, the artifical structures of Malakal Harbor are dominated by large, solitary species of nonindigenous ascidians (unpubl. obs.), while the ascidians of the reefs are primarily native colonial species (Monniot and Monniot 2001).
Naranjo et al. (1996) analyzed the ascidian distribution in the large Mediterranean port of Algeciras Bay, Spain, and separated the species into three fairly distinct groups that differ considerably in their physiological tolerances to wave action, pollutants, sedimentation, and other environmental factors: (a) "exclusively in the outer zone of the bay which settle mainly on natural rock substrates, (b) species more abundant in the inner zone of the bay which settle mainly on artificial substrates, and (c) species found throughout the bay." The same nonindigenous ascidians that occur in numerous warm- 
temperate ports of the world were also common or abundant on artificial structures in Algeciras Bay, but were generally not present elsewhere in the bay. Naranjo et al. (1996) concluded that fouling species, which are primarily nonindigenous ascidians, dominate artificial substrates in the harbor, are tolerant of sedimentation and water stagnation, and grow rapidly in water highly enriched by organic material from runoff and sewage treatment effluents; thus they can be considered indicators of regions of intense environmental stress. Native species prefer natural benthic substrates, especially those near the outside of the bay. They are more sensitive to stress and thus can be considered indicators of relatively undegraded environmental conditions.

Do the results of these studies mean that we can be unconcerned about controlling the introduction of nonindigenous ascidians in tropical waters? Some available information suggests otherwise. In the Gulf of Mexico, the Texas Parks and Wildlife Department has utilized decommissioned offshore oil and gas rigs as artificial reefs (J. Culbertson, pers. comm.). While the rigs are still in place in water up to $70 \mathrm{~m}$ deep, they are cut in half. The bottom half (about $35 \mathrm{~m}$ in height) may be left in place while the top half is sunk either nearby or after being towed to another site. The newly submerged superstructure (walkways, etc.) of the top halves now also becomes available for colonization by marine organisms. In all cases, all of the epibiota that had been growing for many years on the underwater legs of the rigs is left in place and thus may be transported to new locations. Some of these locations are within 1-2 $\mathrm{km}$ or so of exceptionally rich and beautiful underwater reefs such as Flower Garden Banks and Stetson Bank, both protected under the National Marine Sanctuary program. In the past several years a nonindigenous colonial ascidian, Didemnum perlucidum, has completely overgrown all sides of a number of these oil rigs, covering hundreds of square meters and smothering the sponges, bivalves, and other invertebrates that formerly grew on the structures. On a rig that was cut in half in 1997, the upper half sunk next to the lower half and then surveyed 14 months later, D. perlucidum covered $100 \%$ of the rig superstructure that had previously been out of water. A quick survey of the two underwater reefs just mentioned during summer 2000 appears to indicate that $D$. perlucidum is so far restricted to the oil rigs and has not invaded the reefs, but it is a situation that needs to be closely monitored. Any degradation of the natural reefs might give the ascidian the competitive advantage it needs to get a foothold.

Didemnum perlucidum apparently breeds throughout the year, daily releasing large numbers of mature brooded larvae (unpubl. data and J. Culbertson, pers. comm.). $\mathrm{Di}$ demnum perlucidum was described by $\mathrm{F}$. Monniot (1983) from Guadeloupe in the Caribbean, where it grows on both artificial and natural substrates. It was not listed by Van Name (1945) or Plough (1978) for any region in the United States. Thus it may be a recent introduction to the Caribbean or was a minor member of the fauna until its rapid increase and spread within the past few years. $D i$ demnum perlucidum is now a common fouler of artificial surfaces in harbors in Brazil (da Rocha and Monniot 1995) as well as throughout the Indo-West Pacific, including Guam (Paulay et al. 2001), Palau (unpubl. data), French Polynesia, Indonesia, New Caledonia, Zanzibar, and many other areas (reviewed in Monniot and Monniot 1996). It is often abundant, overgrowing other epibionts (especially solitary ascidians) and sometimes hanging in long, thick strands that easily break off and drift away; this may be an important method of spreading, as it appears to be for Perophora japonica (Nishikawa et al. 2000). Both D. perlucidum and Trididemnum solidum are facultative hosts to unicellular photosymbionts such as Procbloron; thus not only can the photosymbionts be transported along with their host ascidian colony but they may make it easier for the host to become established in a new area.

Healthy communities with a high diversity of species seem able to prevent or limit the establishment of nonindigenous ascidians (Stachowicz et al. 1999), though there is some disagreement about this theory. When reefs become degraded or when bacterial levels 
rise, certain species of ascidians may undergo rapid increases. Ascidians are efficient suspension feeders. Bak et al. $(1981,1996,1998)$ studied the coral reefs of the Caribbean island of Curaçao for over 15 yr. Before 1980 the native didemnid Trididemnum solidum was present in small numbers, did not appear to compete with native corals for food and space, and preferred to settle on dead coral with a thin algal turf. However, by $1996 \mathrm{Bak}$ et al. found a $900 \%$ increase in T. solidum, which they attributed at least in part to greatly increased densities of suspended bacteria in the water resulting from a big increase in anthropogenic activities during the $15 \mathrm{yr}$ between the two studies. Trididemnum solidum now actively outcompetes the corals, overgrowing and killing live coral. A similar situation is occurring in the Bay Islands off the coast of Honduras, about $1800 \mathrm{~km}$ from Curaçao, where large mats of $T$. solidum have appeared in the past $2-3 \mathrm{yr}$ and are covering and killing the corals (J. Keck and R. Houston, pers. comm.).

\section{CONCLUSIONS}

Although nonindigenous ascidians are extremely abundant on artificial surfaces in harbors and marinas throughout the world, where they are often the dominant species with an incredibly high biomass, they rarely colonize adjacent natural benthic ecosystems. Healthy natural ecosystems such as coral reefs comprise a high biodiversity, with complex interactions among the species, and this is thought to be an important factor in preventing the establishment of invading species. However, many coral reef areas are becoming degraded due to anthropogenic activities, global warming (including the recent warming due to $\mathrm{El}$ Niño), and perhaps other causes. A number of reports, most of them unpublished as yet, are documenting the rapid spread of several ascidian species over the past several years in various temperate and tropical regions of the world. The reasons for this change are not known, but they do coincide with the latest $\mathrm{El}$ Niño event. These ascidians have not declined with the return of cooler water; on the contrary they continue their rapid spread and overgrowth of other sessile organisms. More frequent dry dock cleaning of boat hulls might help prevent the spread of fouling species (Brock et al. 1999), and perhaps hand removal of invaders in an early stage of invasion might prevent their establishment. Although the mostly nonindigenous biota on artificial structures in harbors has apparently not affected nearby natural areas (Connell. and Glasby 1999), there is still the possibility of long-term and as yet unforeseen changes in adjacent natural ecosystems (Bak et al. 1996, Glasby and Connell 1999), and careful regular monitoring of sensitive natural areas should be carried out.

\section{ACKNOWLEDGMENTS}

I am greatly indebted to G. Paulay and the entire staff of the University of Guam Marine Laboratory for their willing and cheerful assistance in all matters large and small during my stays in Guam, funded by a Sea Grant to G. Paulay. G. Paulay aided by L. Kirkendale, C. Meyer, R. Ritson-Williams, J. Starmer, T. Rongo, and P. Houk collected ascidians by scuba. M. Hadfield, director of the University of Hawai'i Kewalo Laboratory, provided laboratory space; P. and L. Colin of the Coral Reef Research Foundation provided all necessary support for the work in Palau. Many thanks to L. G. Eldredge of the Pacific Science Association for obtaining financial support for my work in Honolulu and participation at the Ninth International Coral Reef Symposium, and to S. Godwin, R. DeFelice, and S. Coles of the Bishop Museum in Honolulu for collection of specimens. J. Culbertson of the Texas Parks and Wildlife Department provided the data on Didemnum perlucidum in the Gulf of Mexico. The manuscript was improved by the suggestions of an anonymous reviewer. I am especially grateful to C. Lambert as always for his unstinting aid with all aspects of this work.

\section{Literature Cited}

Bailey-Brock, J. H. 2000. A new record of the polychaete Boccardia proboscidea (Family 
Spionidae), imported to Hawai'i with oysters. Pac. Sci. 54:27-30.

Bak, R. P. M., J. Sybesma, and F. C. van Duyl. 1981. The ecology of the tropical compound ascidian Trididemnum solidum. II. Abundance, growth and survival. Mar. Ecol. Prog. Ser. 6:43-52.

Bak, R. P. M., D. Y. M. Lambrechts, M. Joenje, G. Nieuwland, and M. L. J. Van Veghel. 1996. Long-term changes on coral reefs in booming populations of a competitive colonial ascidian. Mar. Ecol. Prog. Ser. 133:303-306.

Bak, R. P. M., M. Joenje, I. de Jong, D. Y. M. Lambrechts, and G. Nieuwland. 1998. Bacterial suspension feeding by coral reef benthic organisms. Mar. Ecol. Prog. Ser. 175:285-288.

Berrill, N. J. 1955. The origin of vertebrates. Clarendon Press, Oxford.

Bishop, J. D. D., and A. D. Sommerfeldt. 1996. Autoradiographic investigation of uptake and storage of exogenous sperm by the ovary of the compound ascidian Diplosoma listerianum. Mar. Biol. (Berl.) 125:663-670.

Boyd, H. C., I. L. Weissman, and Y. Saito. 1990. Morphologic and genetic verification that Monterey Botryllus and Woods Hole Botryllus are the same species. Biol. Bull. (Woods Hole) 178:239-250.

Brock, R., J. H. Bailey-Brock, and J. Goody. 1999. A case study of efficacy of freshwater immersion in controlling introduction of alien marine fouling communities: The USS Missouri. Pac. Sci. 53:223-231.

Carlton, J. T., and J. B. Geller. 1993. Ecological roulette: The global transport of nonindigenous marine organisms. Science (Washington, D.C.) 261:78-82.

Coles, S. L., R. C. DeFelice, L. G. Eldredge, and J. T. Carlton. 1999. Historical and recent introductions of non-indigenous marine species into Pearl Harbor, Oahu, Hawaiian Islands. Mar. Biol. (Berl.) 135:147-158.

Connell, S. D. 2000. Floating pontoons create novel habitats for subtidal epibiota. J. Exp. Mar. Biol. Ecol. 247:183-194.

Connell, S. D., and T. M. Glasby. 1999. Do urban structures influence local abundance and diversity of subtidal epibiota? A case study from Sydney Harbour, Australia. Mar. Environ. Res. 47:373-387.

da Rocha, R. M., and F. Monniot. 1995. Taxonomic and ecological notes on some Didemnum species (Ascidiacea, Didemnidae) from São Sebastião Channel, southeastern Brazil. Rev. Bras. Biol. 55:639-649.

Fay, R. C., and J. A. Vallee. 1979. A survey of the littoral and sublittoral ascidians of southern California, including the Channel Islands. Bull. South. Calif. Acad. Sci. 78:122-135.

Glasby, T. M. 2000. Surface composition and orientation interact to affect subtidal epibiota. J. Exp. Mar. Biol. Ecol. 248:177190.

Glasby, T. M., and S. D. Connell. 1999. Urban structures as marine habitats. Ambio 28:595-598.

Lambert, C. C., and G. Lambert. 1998. Nonindigenous ascidians in southern California harbors and marinas. Mar. Biol. (Berl.) 130:675-688.

Monniot, C., and F. Monniot. 1994. Additions to the inventory of eastern tropical Atlantic ascidians; arrival of cosmopolitan species. Bull. Mar. Sci. 54:71-93.

Monniot, C., F. Monniot, and P. Laboute. 1991. Coral reef ascidians of New Caledonia. ORSTOM, Paris.

Monniot, F. 1983. Ascidies littorales de Guadeloupe I. Didemnidae. Bull. Mus. Natl. Hist. Nat., 4th ser., 5:5-49.

Monniot, F., and C. Monniot. 1996. New collections of ascidians from the western Pacific and southeastern Asia. Micronesica 29:133-179.

Monniot, F., and C. Monniot. 2001. Ascidians from the tropical western Pacific. Zoosystema 23:201-383.

Monniot, F., R. Martoja, and C. Monniot. 1993. Tin accumulation in tissues of ascidians from Mediterranean harbours (Corsica, France). C. R. Acad. Sci. 316:588592.

- 1994. Cellular sites of iron and nickel accumulation in ascidians related to the naturally and anthropic enriched New Caledonian environment. Ann. Inst. Oceanogr. 70:205-216. 
Naranjo, S. A., J. L. Carballo, and J. C. Garcia-Gomez. 1996. Effects of environmental stress on ascidian populations in Algeciras Bay (southern Spain). Possible marine bioindicators? Mar. Ecol. Prog. Ser. 144:119-131.

Nishikawa, T., J. D. D. Bishop, and A. D. Sommerfeldt. 2000. Occurrence of the alien ascidian Perophora japonica at Plymouth. J. Mar. Biol. Assoc. U.K. 80:949950.

Nomaguchi, T. A., C. Nishijima, S. Minowa, M. Hashimoto, C. Haraguchi, S. Amemiya, and H. Fujisawa. 1997. Embryonic thermosensitivity of the ascidian, Ciona savignyi. Zool. Sci. (Tokyo) 14:511-516.

Paulay, G., L. Kirkendale, G. Lambert, and J. Starmer. 2001. The marine invertebrate biodiversity of Apra Harbor: Significant areas and introduced species, with focus on sponges, echinoderms and ascidians. Prepared for Naval Activities Guam, under Cooperative Agreement N68711-97-LT70001 .

Plough, H. H. 1978. Sea squirts of the Atlantic continental shelf from Maine to
Texas. Johns Hopkins University Press, Baltimore.

Sims, L. L. 1984. Osmoregulatory capabilities of three macrosympatric stolidobranch ascidians, Styela clava Herdman, S. plicata (Lesueur), and S. montereyensis (Dall). J. Exp. Mar. Biol. Ecol. 82:117-129.

Sings, H. L., K. C. Bible, and K. L. Rinehart. 1996. Acyl tunichlorins: A new class of nickel chlorins isolated from the $\mathrm{Ca}$ ribbean tunicate Trididemnum solidum. Proc. Natl. Acad. Sci. U.S.A. 93:1056010565.

Sommerfeldt, A. D., and J. D. D. Bishop. 1999. Random amplified polymorphic DNA (RAPD) analysis reveals extensive natural chimerism in a marine protochordate. Mol. Ecol. 8:885-890.

Stachowicz, J. J., R. B. Whitlatch, and R. W. Osman. 1999. Species diversity and invasion resistance in a marine ecosystem. Science (Washington, D.C.) 286:15771579.

Van Name, W. G. 1945. The North and South American ascidians. Bull. Am. Mus. Nat. Hist. 84:1-476. 